\title{
NOTE
}

\section{Purification of Human Placental Lactogen}

\author{
AKIHIKo KUMAI \\ Department of Chemistry, Research Laboratories, \\ Teikoku Hormone Mfg. Co., Ltd., Kawasaki, Kanagawa
}

\section{Synopsis}

\begin{abstract}
In order to obtain a more homogeneous preparation of human placental lactogen (HPL), a proteo-hormone which chiefly possesses lactogenic activity, the extraction and the purification of this protein from human placental tissues was carried out by a modification of the method of Friesen $(1965 \mathrm{a}, \mathrm{b})$. The extracts of minced placenta were made to be acetone-dried powder. The powder was extracted with water and then the soluble portion was precipitated with half saturated ammonium sulfate. This crude preparation was fractionated on ECTEOLA-cellulose column and Sephadex G-100 equilibrated with $0.05 \mathrm{M}$ ammonium bicarbonate, $\mathrm{pH}$ 8.3. The preparation thus obtained was electrophoretically homogeneous and showed prominent lactogenic effects in the pigeon crop sac assay. No gonadotropic activity of this protein was observed.
\end{abstract}

Since Ehrhardt (1936) demonstrated lactogenic activity in extracts of human placenta, it has long been one of the most attractive subjects in endocrinology. Recently, human placental lactogen (HPL) which is responsible for this activity was isolated as an entity of protein nature. Although the physiological significance of this protein still have not been fully understood, it might be reasonable to conclude that HPL plays some important roles as a hormone during pregnancy (Iizuka and Nakai (1969b) and Tojo et al. (1969)). It is well recongnized that HPL has slight somatotropic and luteotropic activities besides prominent lactogenic effect (Friesen et al. (1969)).

Lactogenic substance (Ito and Higashi (1953, 1961), Higashi (1961) and Kurosaki (1961)) and growth hormone-like substance (Fukushima (1961)) have already been extracted from human placenta. Subsequently, methods of extraction and purification of HPL have been developed by extraction and

Received for publication December 28, 1970. purification of HPL have been developed by Josimovich and MacLaren (1962), Cohen et al. (1964), Friesen (1965a, b), Turtle et al. (1966), Florini et al. (1966), Catt et al. (1967), Sherwood (1967), Mochizuki and Tojo (1969) and Iizuka and Nakai (1969a).

However, in the methods using DEAEcellulose column chromatography, the separation of this hormone was not sufficient in the following gel filtration and the additional operations were required to obtain highly purified hormone. The use of ECTEOLAcellulose instead of DEAE-cellulose improved the separation of the hormone on gel filtration process and resulted in eliminating further steps. This article will communicate the outline of purification procedure and some properties of the product obtained.

\section{Materials and Methods}

Protein concentrations Protein concentrations were measured by the absorbance at $278 \mathrm{~m} \mu$ using the Hitachi Spectrophotometer. 
Biological assays (a) Lactogenic activity of various preparations was determined by the pigeon crop sac weight gain (Riddle et al., 1933, 1939). (b) Growthpromoting activity was measured using the method of Ando et al. (1963). (c) Gonadotropic effect was assayed by the method of Friedman (1929).

Immunological assays (a) Ouchterlony agar geldiffusion was performed using rabbit anti-HPL serum. Antibodies to HPL were prepared by injection of purified HPL in adjuvant into rabbits. $\mathrm{HGH}$ was kindly donated by Dr. S. Matsushima of the laboratories (prepared by the method of Li (1954)). (b) The reaction with anti-serum against HCG was performed by hemagglutination-inhibition assay using HCGsensitized sheep blood cells - anti-HCG serum system.

Analytical polyacrylamide disc gel electrophoresis was achieved at pH 8.9 in $7.5 \%$ acrylamide gel by the method of Ornstein and Davis (1962).

Procedures for extraction All procedures in the purification were carried out between $4^{\circ}$ and $7^{\circ} \mathrm{C}$. Minced placental tissues were extracted with three times the weight of $0.5 \% \mathrm{KCl}$ solution at $\mathrm{pH} 8.5$ for 3 hr.* After filtration, the pH of the extract was then lowered to 4.6 and it was left overnight in the cold room.

The solution was centrifuged and the supernatant was adjusted to $\mathrm{pH}$ 5.7, then acetone was added to a final concentration of $75 \%$. The solution was left in the cold room for an hour and the precipitate was separated by decantation, washed several times with cold acetone and was dried in a desiccator. Acetonedried powder was extracted in about 20 times its weight of deionized water for $3 \mathrm{hr}$. It was then centrifuged and the supernatant was adjusted to $\mathrm{pH} 5.7$, saturated ammonium sulfate was added to a final concentration of $50 \%$ and this was left overnight in the cold. After the centrifugation the precipitate was suspended in deionized water, dialyzed for two days, and freeze-dried. A $0.5 \%$ solution of the adjusted to 6.5. The precipitate was removed by centrifugation, and freeze-dried. A $0.5 \%$ solution of the freeze-dried matenal in water was prepared, and $\mathrm{pH}$ was adjusted to 6.5 . The precipitate was removed by centrifugation, and then the alove noted ammonium sulfate fractionation at $\mathrm{pH} 5.7$ was repeated in the clear supernatant. The placental crude extract obtained in this way was applied to an ECTEOLA-cellulose (Brown, Lot

* The extract with $0.5 \% \mathrm{KCl}$ solution of human placenta was kindly supplied by the courtesies of Dr. S. Takagi, Department of Obstetrics and Gynecology, Nihon University, School of Medicine, Tokyo and Dr. R. Okamoto, Department of Obstetrics and Gynecology, Tokyo Medical and Dental University, School of Medicine, Tokyo, Japan.
No. 1159) equilibrated with $0.05 \quad M$ ammonium bicarbonate, $\mathrm{pH}$ 8.3. The column was developed by stepwise elution with $0.05 \mathrm{M}, 0.1 \mathrm{M}$ and finally $0.3 \mathrm{M}$ ammonium bicarbonate buffer. After lyophilization, $0.3 M$ fraction was further purified by gel filtration on a column $(3.0 \times 200 \mathrm{~cm})$ of Sephadex G-100 (Pharmacia Fine Chemicals, Lot No. 7362) previously equilibrated with $0.05 M$ ammonium bicarbonate, $\mathrm{pH}$ 8.3 .

\section{Results and Discussion}

The author isolated and purified HPL from human full-term placenta which possesses the remarkable prolactin-like activity. As mentioned above, the biological effects of HPL cover in the wide range. In this study the bioassay was carried out mainly focusing it on lactogenic activity. The results of the tibia test, Friedman's reaction and hemagglutination-inhibition reaction revealed that very slight growth hormone-like, but no gonadotropic activities in this preparation were observed. Luteotropic and free fatty acid mobilizing activities are now under investigation.

As shown in Table 1, the crude extract of human placenta obtained from this extraction procedure (the precipitate with half saturated ammonium sulfate) was active at dose level of $75 \mathrm{mg}$ per pigeon by the crop sac test. ECTEOLA-cellulose column chromatography yielded three peaks of F-1 $(59.5 \%)$,

F-2 $(11.6 \%)$ and F-3 $(7.8 \%$; in their weight of lyophilized preparation, respectively). The fractions were pooled and the biological activities were measured. Most of the lactogenic effect was contained in the fraction eluted with $0.3 \mathrm{M}$ solution (F-3). On Sephadex G-100 column, four peaks were obtained (Fig. 1). The highest lactogenic activity among them was found in the last peak F-3-IV (Table 1). The active fractions from ECTEOLAcellulose and gel filtration were potent at dose level of $20 \mathrm{mg}$ and $1.8 \mathrm{mg}$ in pigeon assay, respectively. In this procedure using ECTEOLA-cellulose, HPL was clearly separated by Sephadex G-100 gel filtration (Fig. 1). 
Table 1. Effect of human placental lactogen on the pigeon crop sac

\begin{tabular}{lcccc}
\hline \hline & $\begin{array}{c}\text { No. of } \\
\text { pigeon }\end{array}$ & $\begin{array}{c}\text { Dose } \\
(\mathrm{mg} / \mathrm{head})\end{array}$ & $\begin{array}{c}\text { Crop sac wt. } \\
(\mathrm{mg})\end{array}$ & $\begin{array}{c}\text { Crop sac wt. } \\
\text { (mg)/body wt. 100g }\end{array}$ \\
\hline $\begin{array}{l}\text { Control } \\
\begin{array}{l}\text { 1st. amm. sulf. } \\
\text { fraction }\end{array}\end{array}$ & 3 & saline & $944 \pm 49$ & $306 \pm 9$ \\
$\begin{array}{l}\text { 2nd. amm. sulf. } \\
\text { fraction } \\
\begin{array}{l}\text { ECTEOLA-cellulose } \\
\text { fraction }\end{array}\end{array}$ & 2 & 200 & $2,750 \pm 150$ & $818 \pm 20$ \\
$\quad$ F-3 & 3 & 75 & $2,463 \pm 188$ & $945 \pm 22$ \\
$\begin{array}{l}\text { Sephadex G-100 } \\
\text { fraction }\end{array}$ & & 20 & $2,890 \pm 96$ & $905 \pm 23$ \\
$\quad$ F-3-IV & 3 & 1.8 & $2,439 \pm 218$ & $779 \pm 54$ \\
\hline
\end{tabular}

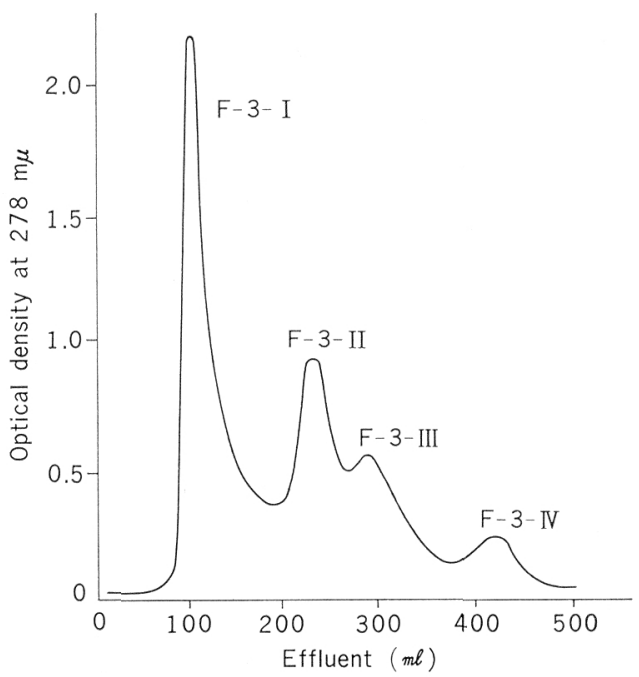

Fig. 1. Sephadex G-100 column chromatogram of the fraction $\mathrm{F}-3$ (150 $\mathrm{mg}) .0 .05 \mathrm{M}$, ammonium bicarbonate, $\mathrm{pH} 8.3$. Column: $3.0 \times 200 \mathrm{~cm}$, Flow rate: $20 \mathrm{~m} /$ per hr.

The protein thus obtained shows almost a single band in disc gel electrophoresis examination as shown in the pattern (Fig. 2) of the analysis of respective purification steps.

These observations suggest that the weak absorption of this hormone on ECTEOLAcellulose, in spite of its extremely low basicity, provided incidentally the partially purified HPL preparation which can be readily isolated from other components by successive

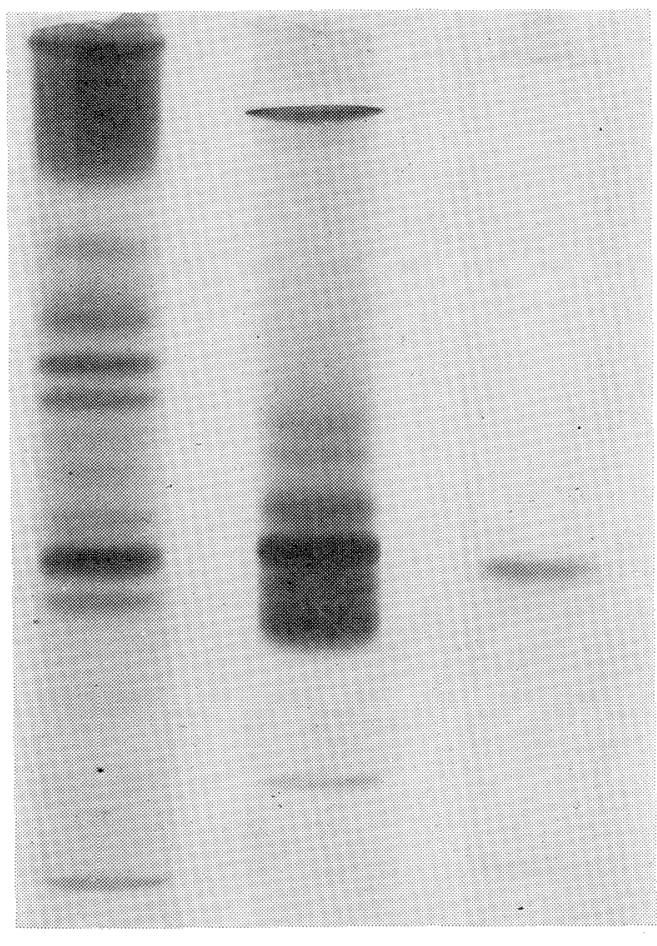

a

b

Fig. 2. Disc electrophoretic pattern at $\mathrm{pH} 8.9$ in $7.5 \%$ acrylamide gel during each step of the purification. The anode $(+)$ is at the bottom. $300 \mathrm{~V}, 3$ $\mathrm{mA}$. (a) fraction by half saturated ammonium sulfate. (b) fraction F-3 in ECTEOLA-cellulose column chromatography. (c) fraction $\mathrm{F}-3-\mathrm{IV}$ in Sephadex G-100 gel filtration. 
gel filtration procedure.

The specific activity of F-3-IV fraction was found to be about 100 times greater than the parent crude preparation by weight in the crop sac test with pigeons as shown in Table 1. This product possesses partially cross reactable antigen with $\mathrm{HGH}$ preparation (Fig. 3 ). The yield in this extraction procedure was approximately $20 \mathrm{mg}$ of F-3-IV on Sephadex G-100 gel filtration per $\mathrm{kg}$ of minced placental tissues.

From the results of biological assays, disc electrophoresis and immunological assays the fraction obtained by gel filtration might account for the highly purified preparation of the so-called human placental lactogen.

This highly purified HPL prepared by the ECTEOLA-cellulose method presented in this note enabled brilliantly the immunofluorescent antibody technique to demonstrate HPL in placental tissue (S. Takagi 1970, personal communication).

\section{Acknowledgement}

The author wishes to express his gratitude to Dr. Y. Kurosawa who afforded an opportunity of performing this work. The author is also indebted to Dr. K. Nakanowatari for undertaking the bioassay of the extract of human placentas. The capable technical help of the staff of the Chemical and the Pharmacological Research Laboratories is gratefully acknowledged

\section{References}

Ando, H., O.Kobayashi, T. Miki and T. Sudo (1963). Folia Endocrinol. Japon. 38, 665. Catt, K. J., B. Moffat, H. D. Niall and B. N. Preston (1967). Biochem. J. 102, 27c.

Cohen, H., M. M. Grumbach and S. L. Kaplan (1964). Proc. Soc. Exptl. Biol. Med. 117, 438.

Ehrhardt, K. (1936). Münch. Med. Wschr. 29, 1163.

Florini, J. R., G. Tonelli, C. B. Breuer, J. Coppola, I. Ringler and P. H. Bell (1966).

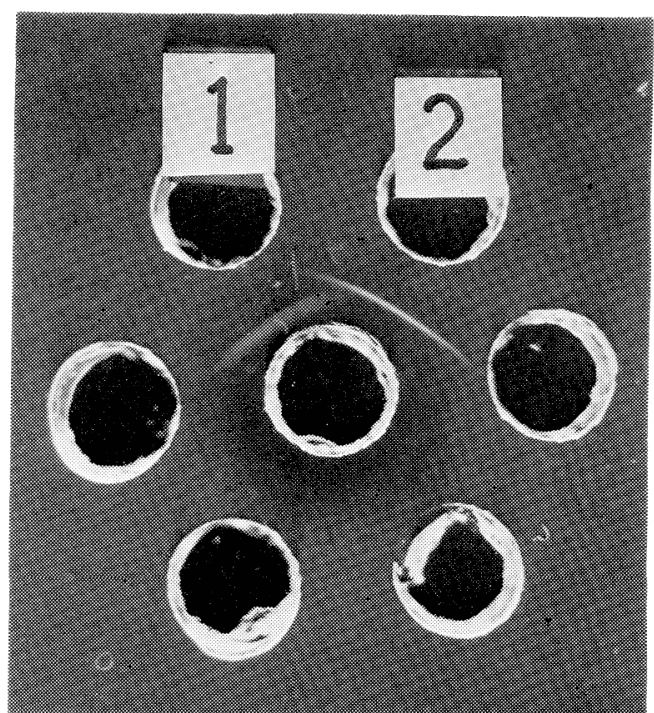

Fig. 3. Gel diffusion by the Ouchterlony method. To the central well rabbit anti-HPL was added. Well 1; HGH $313 \mu \mathrm{g} / \mathrm{m} l$, well 2; HPL $100 \mu \mathrm{g} / \mathrm{m} l$.

Endocrinology 79, 692.

Friedman, H. M. (1929). Am. J. Physiol. 90, 617.

Friesen, H. (1965a). Endocrinology 76, 369. Friesen, H. (1965b). Nature Lond., 208, 1214. Friesen, H., S. Suwa and P. Pare (1969). Rec. Prog. Horm. Res. 25, 169.

Fukushima, M. (1961). Tohoku J. Exper. Med. 74, 161.

Higashi, K. (1961). Endocrinol. Japon. 8, 288. Ito, Y. and K. Higashi (1953). J. Pharm. Soc. Japan. 73, 89.

Ito, Y. and K. Higashi (1961). Endocrinol. Japon. 8, 279.

lizuka, R. and M. Nakai (1969a). Clin. Endocrinol. 17, 26. (In Japanese).

Iizuka, R. and M. Nakai (1969b). The World of Obst. and Gynec. 21, 39. (In Japanese).

Josimovich, J. B. and J. A. MacLaren (1962). Endocrinology 71, 209.

Kurosaki, M. (1961). Tohoku J. Exper. Med. 75, 122.

Li C. H. (1954). J. Biol. Chem. 211, 555.

Mochizuki, M., T. Murata, H. Morikawa, T. Mukuta, K. Okabe, S. Tojo (1970). Folia Endocrinol. Japon. 45, 1121. 
Ornstein, L. and B. J. Davis, preprint by Distillation products Industries. (1962).

Riddle, O. and R. W. Bates, Chapt. XX. Sex and Internal Secretions, 2nd Ed. Williams and Wilkins, Baltimore. (1939).

Riddle, O., R. W. Bates and S. W. Dykshorn (1933). Am. J. Physiol. 105, 191.
Sherwood, L. M. (1967). Proc. Nat. Acad. Sci., U.S. 58, 2307.

Turtle, J. R., P. Beck and W. H. Daughaday (1966). Endocrinology 79, 187.

Tojo, S., M. Mochizuki and T. Murata (1969). Obst. and Gynec. 36, 43. (In Japanese). 